\title{
HPLC and UV-spectrophotometry analysis of flavonoids in spray-dried and freez-dried extracts of Teucrium polium $\mathbf{L}$. (Lamiaceae)
}

\author{
Gjoshe Stefkov $^{1 *}$, Marija Karapandzova ${ }^{1}$, Marina Stefova $^{2}$, Vassya Bankova ${ }^{3}$, \\ Svetlana Kulevanova ${ }^{1}$ \\ ${ }^{1}$ Institute of Pharmacognosy, Faculty of Pharmacy, University Ss Cyril and Methodius, Skopje, Republic of Macedonia \\ ${ }^{2}$ Institute of Chemistry, Faculty of Natural Sciences and Mathematics, University Ss Cyril and Methodius, Skopje, \\ Republic of Macedonia \\ ${ }^{3}$ Department of organic chemistry, Centre for Phytochemistry, BAN, Sofia, Republic of Bulgaria
}

Received: September 2012, Accepted: November 2012

\begin{abstract}
The aim of the study was identification and determination of the content of flavonoids in dry extracts of Teucrium polium, collected from Republic of Macedonia. Two different drying procedures were used, freeze and spray draying. In freeze-dried (FDE) and spray-dried (SDE) extracts of aerial parts of T. polium five flavone aglycones (luteolin, apigenin, cirsiliol, cirsimaritin and cirsilineol) were identified by HPLC method, on the base of retention times and UV spectral data of the components of the extracts in comparison to the authentic samples of flavonoids. Additionally, seven glycosides of apigenin and luteolin were tentatively identified. No significant differences in the composition nor in the content of identified flavonoids were found between both extracts. The content of total flavonoids determined by UV-spectrophotometry with $\mathrm{AlCl}_{3}$ was $72.8 \pm 0.62 \mathrm{mg} \mathrm{Lut} / \mathrm{g}$ and $73.34 \pm 0.53 \mathrm{mg} \mathrm{Lut} / \mathrm{g}$ in FDE and SDE extract of $T$. polium, respectively.
\end{abstract}

Key words: Teucrium polium, freeze-dried extract, spray-dried extract, flavonoids, HPLC analysis, total flavonoids

\section{Introduction}

Teucrium polium L. (Lamiaceae) is widely distributed wild-growing plant in Republic of Macedonia (RM) (Micevski, 1998) and abounds in southwestern Asia, Europe, and North Africa (Mashreghi and Niknia, 2012). This flowering perenial small shrub can grow up to $30 \mathrm{~cm}$ and has a callous white exterior. Infusion of the leaves and flowers is consumed as a appetite stimulating beverage. Some biological and therapeutic effects have been reported for the plant such as anti-oxidant (Kadifkova Panovska et al., 2005; Ardestani et al., 2008; Esmaeili et al., 2009), anti-inflammatory (Tariq et al., 1989; Capasso et al., 1983),

\footnotetext{
*gstefkov@yahoo.com
}

anti-nociceptive (Baluchnejadmojarad et al., 2005; Abdollahi et al., 2003), anti-pyretic (Autore et al., 1984), antimicrobial (Autore et al., 1984; Zerroug et al., 2011), hypolipidemic (Rasekh et al., 2001, Esmaeili and Yazdanparast, 2004; Stefkov et al., 2011), hepatoprotective (Panovska et al., 2007), cytotoxic and apoptotic effects (Rajabalian et al., 2008). It is also found that protects against ethanolinduced gastric mucosal damage (Mashreghi and Niknia, 2012).

Even so, there is a presence of different classes of secondary metabolites, such as diterpenes (Malakov and Papanov, 1983; Marquez and Valverde, 1979), essential oil (Cozzani et al., 2005; Moghtader, 2009; Kabouche et al., 2007), phenylethanoid glycosides (Oganesyan et al.,1991), etc, probably the most important group of compounds in $T$. polium are the flavonoids. Mainly, flavone glycosides with 
highly methylated aglycons are identified until now (Verykokidou-Vitsaropoulou and Vajias, 1986; Rizk et al., 1986; Kawashty et al., 1999; Harborne et al., 1986; Sharififar et al., 2009). Recently was published that freeze-dried extract of T. polium that contain flavonoids posses insulinotropic and antihyperglycemic effects (Stefkov et al., 2011). It is known that freeze-draying or lyophilisation or cryodesication is dehydratation process typically used to preserve a perishable material or make the material more convenient for transport. Freeze-draying works by freezing the material and then reducing the surrounding pressure to allow the frozen water in the material to sublimate directly from the solid phase to the gas phase. Spray-drying is a method of producing a dry powder from a liquid or slurry by rapidly drying with hot gas. This is the preferred method of drying of many thermally-sensitive materials such as food and pharmaceuticals. Today, freeze-dried and spray-dried extracts are the preferable forms of dry extracts in production of herbal medicinal products. Spray-dried extracts are suitable for production of cold water soluble tea and herbal extracts, hot water soluble tea, industrial use for the food and beverage industries, dry sugar mixes, "Ready to Drink" tea beverages, various food products, and tea powder blends like "2 in 1" or "3 in 1" milk mixes. Freeze dried extracts are mainly hot water soluble, suitable for consumer packs of high value products.

Freeze- and spray-drying are different process and works on different ways. The aim of the present study is analysis of flavonoids in dry extracts of T. polium, obtained by two methods of draying, as a part of the first step of eventual standardization of these herbal preparations for further use in production of medicinal products.

\section{Material and methods}

\section{Plant material}

The over-ground parts of the flowering plant Teucrium polim (20-25 $\mathrm{cm}$ from the top) were collected during the summer in 2007 near v. Koleshino, south-east part of R. Macedonia. The plant material was air dried, packed in paper bags and kept in a dark and cool place until analysis. Plant identity was verified and voucher specimens were deposited at the Institute of Pharmacognosy, Faculty of Pharmacy, Skopje, RM.

\section{Reagents and authentic samples}

Reagents of HPLC purity were purchased from Sigma Chemical Co. (Germany). Authentic substances: apigenin and luteolin were products of Extrasynthese (France) and cirsimaritin, cirsilineol and cirsiliol were kindly donated by Dr. B. Voirin from the Laboratoire de Phytochimie, U. E. R. des Sciences de la Nature, Université Claude Bernard Lyon, France.

\section{Preparation of plant extracts}

A quantity of $5 \mathrm{~g}$ of plant material was submitted to hydroalcoholic extraction, in $500 \mathrm{ml}$ ethanol $70 \%(\mathrm{~V} / \mathrm{V})$. The extractions were made with constant mixing on magnetic stirrer for $24 \mathrm{~h}$. To obtain a solid substance, the alcoholic extracts were concentrated in a rotary evaporator to only water residue remained. The concentrated solution was divided in two equal portions.

First portion was spray-dried under following conditions: inlet temperature $110^{\circ} \mathrm{C}$, outlet temperature $69^{\circ} \mathrm{C}$, pump activity $30 \%$, flow rate of extract $8 \mathrm{ml} \mathrm{min}^{-1}$, and aspiration $100 \%$. Atomization pressure was 1.5 bars. This led to obtain spray-dried extract (SDE) of T. polium. The second portion of concentrated extract was freeze-dried on -36 ${ }^{\circ} \mathrm{C}$ under $12 \mathrm{~Pa}$ pressure, $12 \mathrm{~h}$, after previous freezing at $-80{ }^{\circ} \mathrm{C}, 30$ minutes. This led to obtain freeze-dried extract (FDE) of T. polium.

\section{HPLC analysis}

Flavonoid aglycones and glycosides in dried extracts were identified by the HPLC method, using a Varian HPLC system equipped with a ternary pump Model 9012 and UV diode-array detector Model 9065. A reverse phase column C18 (250 x $4.6 \mathrm{~mm}, 5 \mu \mathrm{m}$ particles) was used. The column was stabilized in thermostat on $35^{\circ} \mathrm{C}$ with heater of column (CH-30) and temperature controller (TC-45). The mobile phase consisted of $\mathrm{H}_{2} \mathrm{O}$ with $\mathrm{pH}$ adjusted to 3 with $\mathrm{H}_{3} \mathrm{PO}_{4}(\mathrm{~A})$ and $\mathrm{CH}_{3} \mathrm{CN}(\mathrm{B})$, and the elution program for extracts screening was the following: $0-5 \min 85 \% \mathrm{~A} ; 10$ $20 \min 80 \%$ A; $25-30 \min 75 \%$ A; $40-45 \min 65 \%$ A; 50 $55 \mathrm{~min} 55 \mathrm{~A}$; and $65-70 \mathrm{~min} 35 \mathrm{~A}$. The flow rate was $1 \mathrm{ml}$ $\mathrm{min}^{-1}$, the temperature was set to $35^{\circ} \mathrm{C}$ and the injection volume was $20 \mu \mathrm{l}$ (Stefkov, 2006).

Part of the dried extracts were dissolved in appropriate amount of methanol for HPLC analysis. The elution was monitored in the whole UV range and the chromatograms for flavones screening were best seen at $348 \mathrm{~nm}$, which is in the region where flavones exhibit an absorption maximum. Identification was made according to the retention times and UV spectra of the components compared to those of authentic samples of flavonoids. Semi-quantification of flavones was performed comparing the peak area of flavones in the HPLC chromatograms at $348 \mathrm{~nm}$.

\section{$U V$-spectrophotometry of total flavonoids}

The content of total flavonoid was determined using modified UV-spectrophotometric method for determination of flavonoids by Ph.Eur.7. $10 \mathrm{mg}$ of dry SDE or FDE extracts were hydrolyzed in $50 \mathrm{ml}$ acetone with $2 \mathrm{ml}$ conc. $\mathrm{HCl}$ in a presence of $0.5 \mathrm{ml} 10 \%$ solution of urotropine, 1 h. After cooling the mixture was transferred to $50 \mathrm{ml}$ volumetric flask and filled up with acetone. $20 \mathrm{ml}$ of this were transferred into separating funnel and after adding $20 \mathrm{ml}$ water extracted with ethyl acetate, $3 \times 15 \mathrm{ml}$. Ethyl acetate 
Table 1. Identified flavonoids in spray-dried (SDE) and freez-dried extract (FDE) of Teucrium polium

\begin{tabular}{|c|c|c|c|c|}
\hline Flavone & Structure & $\operatorname{SDE}\left(t_{R}\right)$ & $\operatorname{FDE}\left(t_{\mathrm{R}}\right)$ & $\mathrm{St}\left(\mathrm{t}_{\mathrm{R}}\right)$ \\
\hline Apigenin-glycoside & - & 5.80 & 5.81 & - \\
\hline Luteolin-glycoside & - & 14.30 & 14.35 & - \\
\hline Luteolin-glycoside & - & 15.41 & 15.47 & - \\
\hline Apigenin-glycoside & - & 16.53 & 16.57 & - \\
\hline Apigenin-glycoside & - & 17.74 & 17.79 & - \\
\hline Apigenin-glycoside & - & 18.80 & 18.84 & - \\
\hline Apigenin-glycoside & - & 20.67 & 20.70 & - \\
\hline Luteolin & 3',4',5,7-tetrahydroxyflavone & 31.35 & 31.39 & 31.35 \\
\hline Apigenin & 4',5,7-trihydroxyflavone & 41.20 & 41.23 & 41.21 \\
\hline Cirsiliol & 3',4',5-trihydroxy-6,7-dimethoxyflavone & 43.24 & 43.28 & 43.25 \\
\hline Cirsimaritin & 4',5-Dihydroxy-6,7-dimethoxyflavone & 52.20 & 52.22 & 52.23 \\
\hline Cirsilineol & 4',5-dihydroxy-3',6,7-trimethoxyflavone & 53.70 & 53.74 & 53.72 \\
\hline
\end{tabular}

St - mixture of standard substances of flavonoids

fractions were collected together, washed with water, $3 \mathrm{x}$ $25 \mathrm{ml}$, dried with anhydrous $\mathrm{Na}_{2} \mathrm{SO}_{4}$, filtrated into another $50 \mathrm{ml}$ volumetric flask and filled up with ethyl acetate. 10 $\mathrm{ml}$ of this was used for developing complex with $1 \mathrm{ml} \mathrm{Al-}$ $\mathrm{Cl}_{3}$ in $25 \mathrm{ml}$ volumetric flask, filled up with acetic methanol. The absorbance was measured after $30 \mathrm{~min}$ at $390 \mathrm{~nm}$, against the same prepared solution without $\mathrm{AlCl}_{3}$ used as a blank. The content of total flavonoids was expressed in term of luteolin equivalent (mg Lut / g extract). All meausures were repeated three times.

\section{Results and discussion}

Spray-dried extract of T. polium (SDE) was dry, pale green, amorphous powder with characteristic smell and extremely bitter taste, with $3.73 \%$ moisture. Freez-dried extract (FDE) was dry, dark green powder with characteristic smell, extremely bitter taste and 3.27\% moisture.

The HPLC analysis of dissolved dry extract in methanol $\left(1 \mathrm{mg} \mathrm{ml}^{-1}\right)$ and comparison of the retention times and UV spectral data of selected picks with the appropriate data obtained for standard substances showed presence of 5 different flavones in both dried extracts of T. polium and seven glycosides of apigenin and luteolin (Table 1). The free flavone aglycones could be easily identified as luteolin, apigenin, cirsiliol, cirsimaritin and cirsilineol. Identification of the flavone-glycosides was made tentatively as apigenin- and luteolin-glycosides, identified in both, SDE and FDE, extracts of $T$. polium, recognized by comparing the $\mathrm{UV}$-spectral data with literature and previously published data (Andersen and Markham, 2006). The obtained HPLC chromatograms are presented in Fig. 1.

The obtained results showed no differences in the composition of flavonoids (Table 1, Fig. 1.), in both dry extracts of $T$. polium identical free flavones and flavone glycosides were identified. Semi-quantitative analysis of peak area of the components in the extracts have shown almost identical abundance of identified flavonoids (Table 2).

Table 2. Semi-quantitative HPLC analysis of flavonoids in spray-dried (SDE) and freez-dried extract (FDE) of Teucrium polium

\begin{tabular}{lcc}
\hline \hline Flavone & SDE & FDE \\
\hline Apigenin-glycoside & + & + \\
Luteolin-glycoside & + & + \\
Luteolin-glycoside & + & + \\
Apigenin-glycoside & + & + \\
Apigenin-glycoside & + & + \\
Apigenin-glycoside & + & + \\
Apigenin-glycoside & + & + \\
Luteolin & + & + \\
Apigenin & +++ & +++ \\
Cirsiliol & +++ & +++ \\
Cirsimaritin & + & + \\
Cirsilineol & tr & tr \\
\hline
\end{tabular}

$(+)$ - present; $(+++)$ - dominate; $\operatorname{tr}-$ trace amounts

\section{The content of total flavonoids}

Determination of the content of flavonoids can be made by different methods and most often HPLC or UVspectrophotometry with $\mathrm{AlCl}_{3}$ (complex-making reagent) are used. In case when appropriate authentic substances of flavonoids were not commercially available such it was the case with $T$. polium flavone glycosides, UV-spectrophotometry was chosen as more appropriate. The content of flavonoids was expressed in terms of luteolin equivalent (the standard curve equation of luteolin was: $\mathrm{y}=0.0132+$ $\left.0.0044 ; \mathrm{R}^{2}=0.9993\right), \mathrm{mg}$ Lut/g extract. The obtained results showed no significant differences in the content of to- 


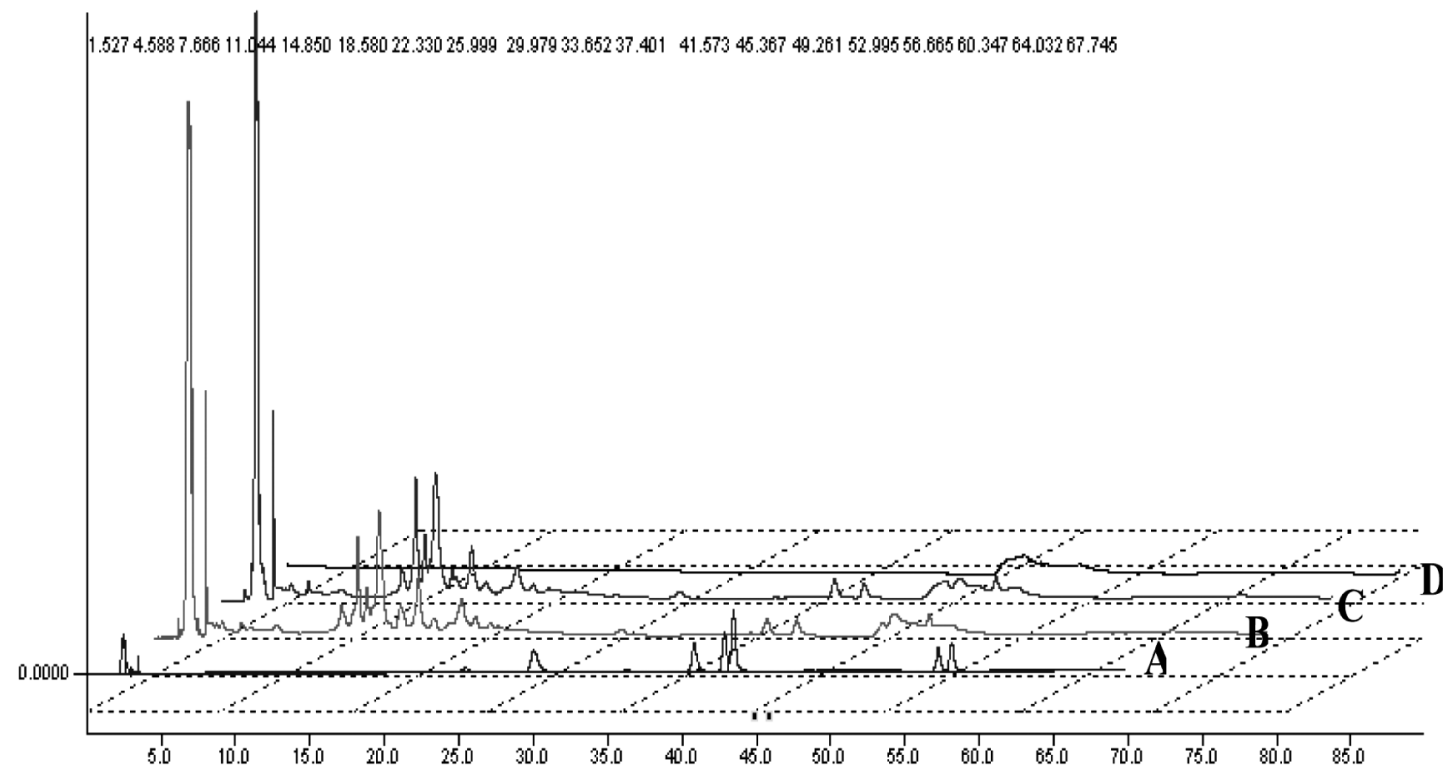

Fig. 1. HPLC chromatograms of mixture of standard substances (A), SDE extract (B), FDE extract (C) and blank (D).

tal flavonoids as $72.8 \pm 0.62 \mathrm{mg} \mathrm{Lut} / \mathrm{g}$ and $73.34 \pm 0.53 \mathrm{mg}$ Lut/g was found in FDE and SDE extract of T. polium, respectively. These are the first results on content of total flavonoids in dry extract of T. polium. Previously, it was reported that dried aerial parts of $T$. polium from RM contain $0.2 \%$ of total flavonoids, determined by UV-spectrophotometry (Kadifkova Panovska et al., 2005).

\section{Conclusion}

In freeze-dried (FDE) and spray-dried (SDE) extracts of aerial parts of T. polium five flavone aglycones (luteolin, apigenin, cirsiliol, cirsimaritin and cirsilineol) were identified by HPLC method, on the base of retention times and UV spectral data of the components of the extracts in comparison to the authentic samples of flavonoids. Additionaly seven glycosides of apigenin and luteolin were tentatively identified. No differences in the composition or in the semi-quantitative abundance of identified flavonoids were found between both extracts, in spite of differences in draying procedure. The content of total flavonoids determined by UV-spectrophotometry with $\mathrm{AlCl}_{3}$ was $72.8 \pm$ $0.62 \mathrm{mg} \mathrm{Lut} / \mathrm{g}$ and $73.34 \pm 0.53 \mathrm{mg} \mathrm{Lut} / \mathrm{g}$ in FDE and SDE extract of $T$. polium, respectively.

\section{References}

Abdollahi, M., Karimpour, H., Monsef-Esfehani, H.R., 2003. Antinociceptive effects of Teucrium polium L. total extract and essential oil in mouse writhing test, Pharmacol. Res. 48, 31-35.

Andersen, Q.M., Markham, K.R., 2006. FLAVONOIDS, Chemistry, Biochemistry and Applications, Taylor \& Francis Group, ISBN 0-8493-2021-6. Accessed at: http://www.uctm-biotechnology. org/Flavonoids.pdf
Ardestani, A., Yazdanparast, R., Jamshidi, S., 2008. Therapeutic effects of Teucrium polium extract on oxidative stress in pancreas of streptozotocin-induced diabetic rats, J. Med. Food 11, 525-532.

Autore, G., Capasso, F., De Fusco, R., Fasulo, M.P., Lembo, M., Mascolo, N. and Menghini, A., 1984. Antipyretic and antibacterial actions of Teucrium polium (L.)., Pharmacol Res Commun. 16, 21-29.

Baluchnejadmojarad, T., Roghani, M. Roghani-Dehkordi, F., 2005. Antinociceptive effect of Teucrium polium leaf extract in the diabetic rat formalin test, J. Ethnopharmacol. 97, 207210.

Capasso, F., Cerri, R., Morrica, P. and Senatore, F., 1983. Chemical composition and anti-inflammatory activity of an alcoholic extract of Teucrium polium L., Boll. Soc. Ital. Biol. Sper. 59, 1639-1643.

Cozzani, S., Muselli, A., Desjobert, J., Bernardini, A., Tomi, F., Casanova, J., 2005. Chemical composition of essential oil of Teucrium polium subsp.capitatum (L.) from Corsica, Flavour and Fragrance Journal 20 (4), 436-441.

Esmaeili, M.A. and Yazdanparast, R., 2004. Hypoglycaemic effect of Teucrium polium: studies with rat pancreatic islets, J. Ethnopharmacol. 95, 27-30.

Esmaeili, M.A., Zohari, F., Sadeghi, H., 2009. Antioxidant and protective effects of major flavonoids from Teucrium polium on beta-cell destruction in a model of streptozotocin-induced diabetes, Planta Med. 75, 1418-1420.

European pharmacopoeia $7^{\text {th }}$ edition, 2010. Concil of Europe, Strasbourg.

Harborne, J.B., Tomas-Barberan, F.A., Williams C.A., Gil, M.I., 1986. A chemotaxonomic study of flavonoids from European Teucrium species, Phytochemistry 25 (12), 2811-2816.

Kabouche, A., Kabouche, Z., Ghannadi, A., Sajjadi, S.E., 2007. Analysis of the essential oil of Teuctrium polium ssp. aurasiaticum from Algeria, J. Essent. Oil. Res. 19, 44-46.

Kadifkova Panovska, T., Kulevanova, S., Stefova, M., 2005. In vitro antioxidant activity of some Teucrium species 
(Lamiaceae), Acta Pharm. 55(2), 207-14.

Kawashty S.A., Gamal El-Din E.M., Saleh N.A.M., 1999. The flavonoid chemosystematics of two Teucrium species from Southern Sinai, Egypt, Biochemical Systematics and Ecology 27, 657-660.

Malakov, P.Y., $\quad$ Papanov, G.Y., 1983. Furanoid diterpenes from Teucrium polium, Phytochemistry 22 (12), 2791-2793.

Marquez, C., Valverde, S., 1979. A new clerodane diterpene from Teucrium polium L., J. Chem. Soc., Perkin Trans. 1, 2526-2527. DOI: 10.1039/P19790002526

Mashreghi, M., and Niknia, S., 2012. The Effect of Peganum harmala and Teucrium polium Alcoholic Extracts on Growth of Escherichia coli O157, Jundishapur J Microbiol. 5(3), 511-515. DOI: $10.5812 / \mathrm{jjm} .3665$

Micevski, K., 1998. Flora of the Republic of Macedonia, Macedonian Academy of Science and Art (Flora na Republika Makedonija, Makedonskata akademija na naukite i umetnostite), Skopje, Republic of Macedonia.

Moghtader, M., 2009. Chemical composition of the essential oil of Teucrium polium L. from Iran, American-Eurasian J. Agric. \& Environ. Sci. 5 (6), 843-846. Accessed at: http:// www.idosi.org/aejaes/jaes5(6)/18.pdf

Oganesyan, G.B., Galstyan, A.M., Mnatsakanyan, V.A., Shashov, A.S., Agababyan, P.V., 1991. Phenilpropanoid glycosides of Teucrium polium, Chemistry of natural compounds 27 (5), 556-559. DOI: 10.1007/BF00630353/

Panovska, T.K., Kulevanova, S., Gjorgoski, I., Bogdanova, M., Petrushevska, G., 2007. Hepatoprotective effect of the ethyl acetate extract of Teucrium polium L. against carbontetrachlorideinduced hepatic injury in rats, Acta Pharm. 57, 241-248.
Rajabalian, S., 2008. Methanolic extract of Teucrium polium L. potentiates the cytotoxic and apoptotic effects of anticancer drugs of vincristine, vinblastine and doxorubicin against a panel of cancerous cell lines. Exp. Oncol. 30, 133-138.

Rasekh, H.R., Khoshnood-Mansourkhani, M. J., Kamalinejad, M., 2001. Hypolipidemic effects of Teucrium polium in rats, Fitoterapia 72, 937-939.

Rizk, A.M, Hammouda, F.M, Rimpler, H., Kamel, A., 1986. Iridoids and flavonoids of Teucrium polium herb, Planta Med. (2), 87-88.

Sharififar, F., Dehghn-Nudeh, G., Mirtajaldini, M., 2009. Major flavonoids with antioxidant activity from Teucrium polium L., Food Chemistry 112, 885-888.

Stefkov, G., 2006. Pharmacognostical investigations on Teucrium polium L. and the other representatives form the genus Teucrium in the flora of Republic of Macedonia, MSci thesis, Faculty of Pharmacy, University Ss Cyril and Methodius, Skopje, Republic of Macedonia.

Stefkov, G., Kulevanova, S., Miova, B., Dinevska-Kjovkarovska, S., Mølgaard, P., Jäger, A.K., Josefsen, K., 2011. Effects of Teucrium polium spp. capitatum flavonoids on the lipid and carbohydrate metabolism in rats. Pharm Biol. 49 (9),88592.

Tariq, M., Ageel, A.M., al-Yahya, M.A., Mossa, J. S. and al-Said, M.S., 1989. Anti-inflammatory activity of Teucrium polium, Int. J. Tissue React. 11, 185-188.

Verykokidou-Vitsaropoulou, E. and Vajias C., 1986. Methylated Flavones from Teucrium polium, Planta Med. 5, 401-402.

Zerroug, M.M., Zouaghi, M., Boumerfeg, S., Baghiani, A., Nicklin, J. Arrar, L., 2011. Antibacterial Activity of Extracts of Ajuga Iva, and Teucrium polium, Advances in Environmental Biology 5(2), 491-495.

\title{
HPLC and UV-спектрофотометриска анализа на флавоноиди во суви екстракти од Teucrium polium L. (Lamiaceae), добиени со спреј сушење и со лиофилизација
}

\author{
Ѓоше Стефков ${ }^{1 *}$, Марија Карапанџова ${ }^{1}$, Марина Стефова ${ }^{2}$, Васја Банкова $^{3}$, \\ Светлана Кулеванова ${ }^{1}$
}

\author{
${ }^{1}$ Институт за фармакогнозија, Фармаиевтски факултет, Универзитет „Св. Кирил и Методиј“, \\ Скопје, Република Македонија \\ ${ }^{2}$ Институт за хемија, Природно-математички факултет, Универзитет „Св. Кирил и Методиј“, \\ Скопје, Република Македонија \\ ${ }^{3}$ Департмент за органска хемија, Центар за фитохемија, БАН, Софија, Република Бугарија
}

Клучни зборови: Teucrium polium, лиофилизиран екстракт, спреј-сушен екстракт, флавоноиди, HPLC анализа, вкупни флавоноиди

Цел на испитувањето е идентификација и определување на содржина на флавоноиди во суви екстракти од Teucrium polium, coбран од Република Македонија. Користени се две различни постапки за сушење, постапка со лиофилизација и постапка на спрејсушење. Во лиофилизираните (FDE) и во спреј-сушените (SDE) екстракти од надземните делови на T. polium, co HPLC анализа и врз база на ретенционите вемиња и UV спектралната анализа, идентификувани се пет флавонски агликони (лутеолин, апиге- 
нин, цирсилиол, цирсимаритин и цирсилинеол), во споредба со автентични примероци од флавоноиди. Дополнително, тентативно се идентификувани седум различни хетерозиди на апигенин и лутеолин. Во двата екстракти не се забележани разлики ниту во составот ниту во содржината на идентификуваните флавоноиди. Содржината на вкупните флавоноиди е определена со UVспектрофотометрија со $\mathrm{AlCl}_{3}$ и изнесува $72.8 \pm 0.62 \mathrm{mg} \mathrm{Lut} / \mathrm{g}$ и $73.34 \pm 0.53 \mathrm{mg} \mathrm{Lut} / \mathrm{g}$ во FDE и SDE екстракт од T. polium, соодветно. 